\title{
Perinatal stress, brain inflammation and risk of autism-Review and proposal
}

Asimenia Angelidou ${ }^{1,6,8+}$, Shahrzad Asadi ${ }^{1,5+}{ }^{+}$, Konstantinos-Dionysios Alysandratos ${ }^{1,6,9}$, Anna Karagkouni ${ }^{1}$, Stella Kourembanas ${ }^{7}$, and Theoharis C Theoharides ${ }^{1,2,3,4,6^{*}}$

\begin{abstract}
Background: Autism Spectrum Disorders (ASD) are neurodevelopmental disorders characterized by varying deficits in social interactions, communication, and learning, as well as stereotypic behaviors. Despite the significant increase in ASD, there are few if any clues for its pathogenesis, hampering early detection or treatment. Premature babies are also more vulnerable to infections and inflammation leading to neurodevelopmental problems and higher risk of developing ASD. Many autism "susceptibility" genes have been identified, but "environmental" factors appear to play a significant role. Increasing evidence suggests that there are different ASD endophenotypes.
\end{abstract}

Discussion: We review relevant literature suggesting in utero inflammation can lead to preterm labor, while insufficient development of the gut-blood-brain barriers could permit exposure to potential neurotoxins. This risk apparently may increase in parents with "allergic" or autoimmune problems during gestation, or if they had been exposed to stressors. The presence of circulating auto-antibodies against fetal brain proteins in mothers is associated with higher risk of autism and suggests disruption of the blood-brain-barrier (BBB). A number of papers have reported increased brain expression or cerebrospinal fluid (CSF) levels of pro-inflammatory cytokines, especially TNF, which is preformed in mast cells. Recent evidence also indicates increased serum levels of the proinflammatory mast cell trigger neurotensin (NT), and of extracellular mitochondrial DNA (mtDNA), which is immunogenic. Gene mutations of phosphatase and tensin homolog (PTEN), the negative regulator of the mammalian target of rapamycin (mTOR), have been linked to higher risk of autism, but also to increased proliferation and function of mast cells.

Summary: Premature birth and susceptibility genes may make infants more vulnerable to allergic, environmental, infectious, or stress-related triggers that could stimulate mast cell release of pro-inflammatory and neurotoxic molecules, thus contributing to brain inflammation and ASD pathogenesis, at least in an endophenotype of ASD patients.

Keywords: Allergy, Autism, Brain, Inflammation, Mast cells, Prematurity, Stress

\section{Review}

\section{Background}

Autism Spectrum Disorders (ASD) are pervasive neurodevelopmental disorders that include autistic disorder, Asperger's disorder, and Pervasive Developmental Disorder-Not Otherwise Specified (PDD-NOS) [1,2].

\footnotetext{
* Correspondence: theoharis.theoharides@tufts.edu

${ }^{\dagger}$ Equal contributors

'Molecular Immunopharmacology and Drug Discovery Laboratory, Department of Molecular Physiology and Pharmacology, Tufts University School of Medicine and Tufts Medical Center, Boston, MA 02111, USA ${ }^{2}$ Department of Biochemistry, Tufts University School of Medicine and Tufts Medical Center, Boston, MA 02111, USA

Full list of author information is available at the end of the article
}

ASD are characterized by variable deficits in communication and social skills, a wide range of behavioral and learning problems and stereotypic behaviors. ASD manifest during early childhood and at least 30\% of cases present with sudden clinical regression of development around 3 years of age often after acute episodes, such as a viral infection or following a vaccination $[3,4]$. Over the last 20 years, there has been an impressive increase in ASD prevalence of about $15 \%$ per year with current estimates of $0.5-1 \%$ of children [5,6]. A study from South Korea reported even higher rates in undiagnosed school children with ASD-like behaviors [7]. A recent report from the US Centers for Disease Control estimated that 1/88

\section{Biomed Central}


children may be affected by ASD (http://www.cdc.gov/ Features/CountingAutism/). In the majority of cases, however, the cause of ASD is unknown [8], in spite of the apparent increase in ASD prevalence [9-11]. We propose that a number of perinatal factors contribute to focal brain inflammation and thus ASD (Figure 1).

\section{Prematurity}

The contribution of perinatal, genetic, and immune factors in ASD was reviewed [12,13]. Premature births (less than 37 weeks gestation) have been increasing and currently account for $15 \%$ of all births in the US [14]. Infants less than 28 weeks gestation are at the highest risk for long-term neurologic problems. Placental dysfunction is a major cause of prematurity, along with intra-uterine infections and auto-immunity, which may also contribute to autism in the offspring due to anoxia [15]. An additional 5-8\% of deliveries are complicated by pre-eclampsia or gestational diabetes, which may lead to placental insufficiency, abnormal growth, and postnatal metabolic imbalance [16]. In utero inflammation or infection can lead to preterm labor and premature birth [17-19]. A retrospective study that investigated rates of autism in children born in Atlanta, GA through the Metropolitan Atlanta Developmental Disabilities Surveillance Program (1981-93) who survived to three years of age, reported that birth prior to
33 weeks gestation was associated with a two-fold higher risk of autism [20]. A prospective study of all births less than 26 weeks gestation in 1995 in the United Kingdom and Ireland also concluded that preterm children are at increased risk for ASD in middle childhood, compared with their term-born classmates [21].

\section{Neurodevelopmental problems due to prematurity}

Infants born between 32 and 36 weeks account for a significant increase in the rate of prematurity in the recent years [22] and are also at risk for neurologic injury [23-26]. Studies evaluating neurobehavioral outcomes following preterm birth reveal a "preterm behavioral phenotype" characterized by inattention, anxiety and social interaction difficulties, and learning difficulties $[27,28]$.

Intra-uterine inflammation [29] can also lead to fetal brain injury and is associated with long-term adverse neurodevelopmental outcomes for the exposed offspring [30], especially in premature infants $[31,32]$. Cerebellar hemorrhagic injury, in particular, is associated with a high prevalence of neurodevelopmental disabilities in infants surviving premature birth [33]. A recent study reported that neonatal jaundice was associated with ASD [34].

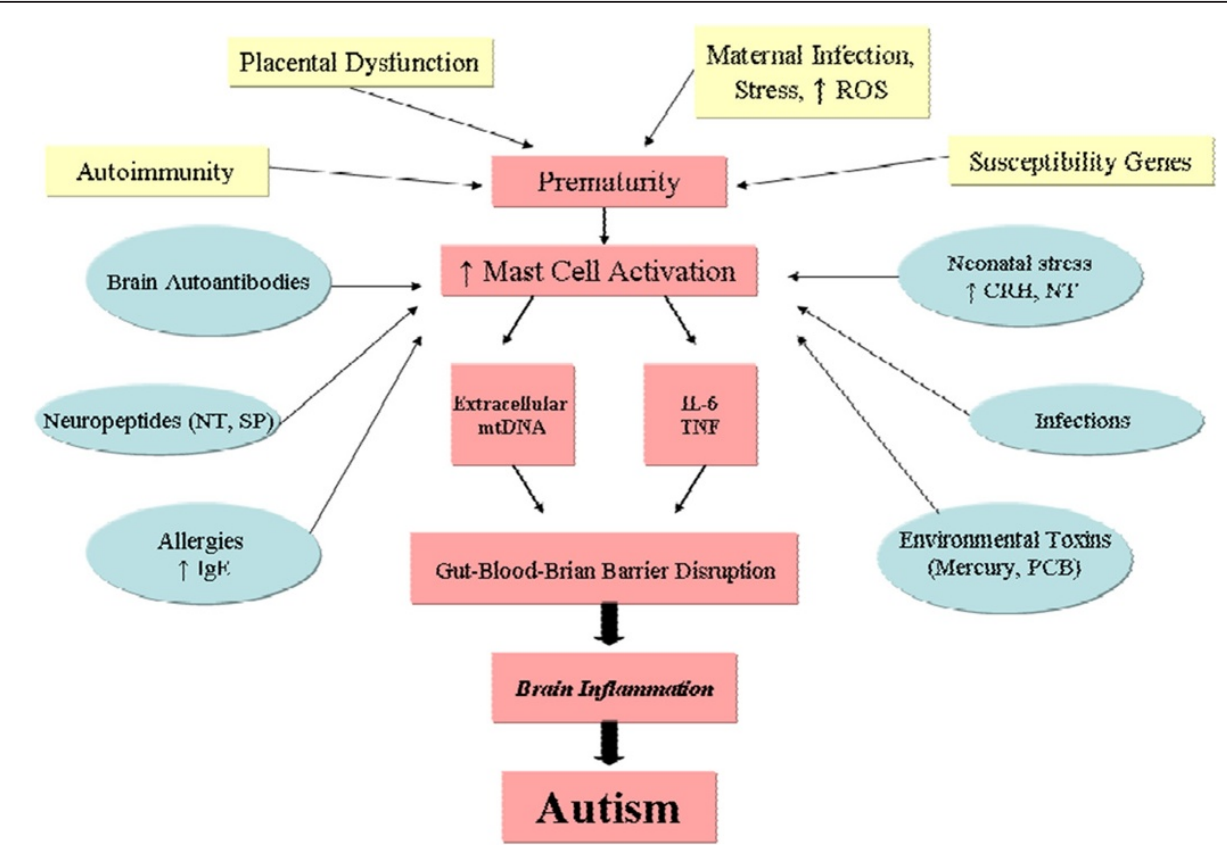

Figure 1 Diagrammatic representation of proposed events and interactions during the perinatal period that may contribute to autism. Placental dysfunction, as well as autoimmunity, maternal infection and gestational stress lead to prematurity. Defective neuronal development and susceptibility genes make the infant vulnerable to environmental triggers that activate mast cells to release mediators that disrupt the gutblood-brain barriers causing brain inflammation. $C R H$, corticotropin-releasing hormone; lgE, immunoglobulin E; IL, interleukin; LPS, lipopolysaccharide; $M C P-1$, macrophage chemo-attractant protein-1; mTDNA, mitochondrial DNA; NT, neurotensin; PCB, polychlorinated biphenyl; ROS, reactive oxygen species; SP, substance P; TNF, tumor necrosis factor. 
Changes in the fetal brain lead to changes in gene expression patterns into the neonatal period. In fact, the lower the intelligence quotient (IQ), the more likely a child may display an ASD behavior [35]. One study of 1129 singleton children identified through school and health record review as having an ASD by age 8 years showed that mean IQ was significantly $(\mathrm{p}<0.05)$ lower in preterm compared to term children, and term-born small-for-gestational age compared to appropriate-for-gestational age infants [36]. Gestational immune activation was reported to perturb social behaviors in genetically vulnerable mice [37].

\section{Low birth weight and prematurity}

Results from different studies strongly suggest that prematurity and/or low birth weight (LBW) increase the risk of ASD in the offspring. One prospective study assessed 91 very LBW ( $<1500 \mathrm{~g}$ ) infants, who had been born preterm, at a mean age of 22 months, and found $26 \%$ of them were likely to develop autism as suggested by a positive modified checklist for autism in toddlers (M-CHAT) test [38]. Another study showed that the diagnostic prevalence of ASD in this LBW $(<2000 \mathrm{~g})$ preterm cohort was higher than that reported by the Centers for Disease Control and Prevention for 8-yearolds in the general US population in 2006 [39]. A recent study found a higher risk of infantile autism among children with LBW, but suggested that suboptimal birth conditions are not an independent risk factor for infantile autism that was increased for mothers older than 35 years, with foreign citizenship, and mothers who used medicine during pregnancy [40].

\section{Perinatal factors contributing to higher risk of ASD}

The conditions leading to premature birth may be more important than prematurity per se. For instance, the increased risk of ASD related to prematurity appeared to be mostly attributed to perinatal complications that occur more commonly among preterm infants, as shown in a cohort of 164 families with autistic children in New Jersey [41]. This was confirmed in a Swedish populationbased case-control study [42]. Other population-based studies suggest that suboptimal birth conditions are not independent risk factors, but rather act as clusters to increase the risk of infantile autism [40]. A case-control population- based cohort study among Swedish children (born in 1974-1993) reported that the risk of autism was associated with daily maternal smoking in early pregnancy, maternal birth outside Europe and North America, cesarean delivery, being small-for-gestational age, a 5-minute APGAR score below 7, and congenital malformations; no association was found between autism and twin birth, head circumference, maternal diabetes, or season of birth [43].
Interestingly, a cohort study of infants born in Canada (between 1990-2002) concluded that perinatal risk factors (including prenatal, obstetrical and neonatal complications) may constitute independent risk factors for development of autism, but only for those children without a genetic susceptibility, while they appear not to influence autistic outcomes among genetically susceptible children [44]. Nevertheless, a meta-analysis on risk factors for autism concluded that there is insufficient evidence to implicate individual perinatal factors in ASD because significant association may have been observed by chance after multiple testing [45]. To the other extreme end of the spectrum, one paper had reported that estimated gestation greater than 42 weeks was associated with autism, but may play less of a role in high-functioning ASD individuals than suggested in studies of autism associated with severe retardation [46].

\section{Obesity}

Perinatal nutritional status was shown to be related to the epigenetic status in adulthood [47]. High weight gain in pregnancy has been considered an independent risk factor for ASD in the offspring [48]. This is interesting in view of the fact that obesity has been considered an inflammatory state [49] involving release of adipocytokines [50]. Leptin is higher in obese subjects [51,52] and elevated plasma leptin levels during pregnancy are indicative of placental dysfunction [53]. Elevated plasma leptin levels were reported in children with regressive autism $(n=37)$, compared with typically-developing controls $(n=50)$ [54]. Another paper reported significantly higher leptin values in 35 patients with autistic disorder aged $18014.1 \pm 5.4$ years old versus controls both at baseline and after one year of follow-up [55]. Plasma levels of leptin were also significantly increased in Rett syndrome $(n=16)$ compared to healthy controls $(n=16)$, irrespective of obesity [55]. However, there is no evidence of either a direct relationship or any role in ASD pathogenesis.

In rats, neonatal leptin administration late in the phase of developmental plasticity was able to reverse the developmental programming [56]. Mast cells also express leptin and leptin receptors, a finding implicating paracrine or autocrine immunomodulatory effects of leptin on mast cells [57].

\section{Genetics and environmental factors}

Increasing evidence suggests that there are different ASD endophenotypes [58], possibly due to the many autism "susceptibility" genes identified [59]. In certain genetic diseases, such as Fragile $\mathrm{X}$ syndrome or tuberous sclerosis, autistic symptoms affect approximately $40-45 \%$ of patients [60]. Similarly, in Rett syndrome, almost $50 \%$ of patients develop ASD [61]. 
There is strong evidence of genetic predisposition with high rates of ASD in twins [62].

Nevertheless, a recent study of identical and fraternal twin pairs with autism showed that genetic susceptibility to ASD was lower than estimates from prior twin studies of autism, with environmental factors common to twins explaining about 55\% of their risk for developing autism [63]. This partial penetration may be the result of interactions between susceptibility genes and "environmental" factors [10,64]. Environmental signals can activate intracellular pathways during early development and lead to epigenetic changes in neural function [65].

A number of mutations involving the regulatory molecule mTOR [66] and its negative control molecule Pten [67] have been linked to autism. In particular, mutations affecting mTOR have been associated with Tuberous Sclerosis I \& II, but also with macrocephaly and abnormal social interactions in other diseases, such as Cowden disease [67]. Activation of mTOR [68] and reduced Pten activity [69] are also associated with increased mast cell proliferation and function.

An epidemiologic study, nested within a cohort of 698 autistic children in Denmark, concluded that perinatal environmental factors and parental psychopathology act independently to increase the risk of autism [70]. Moreover, it was recently shown that use of psychotropic medications by the mother, especially in the third trimester of pregnancy, substantially increases the risk of ASD [71]. Finally, use of general anesthesia in the newborn period was recently shown to lead to neurodevelopmental problems, such as ADHD [72,73].

Environmental toxins such as mercury [74] and polychlorinated biphenyl (PCB) [75] have been implicated in developmental neurotoxicity [76] and have been associated with ASD. Both mercury and PCBs can also stimulate mast cells [77-79].

\section{Oxidative stress}

Several studies have suggested a link between oxidative stress and the immune response [80]. Maternal infection and inflammation can lead to oxidative stress, such as increased lipid peroxidation, but more importantly to alterations in the expression of many genes associated with adverse perinatal outcomes [81]. Oxidative stress initiated by environmental factors in genetically vulnerable individuals leads to impaired methylation and neurological deficits secondary to reductions in methylation capacity [52]. One study showed increased levels of plasma malondialdehyde, a marker of oxidative stress, in the blood of mothers who delivered preterm and in the cord blood of their preterm neonates, compared to the levels in samples from term deliveries [82]. Preterm birth was associated with increased generation of reactive oxygen species (ROS) [83]. In fact, a recent study identified an increase in the oxidative stress marker non-protein bound iron (NPBI) in the cord blood of 168 preterm newborns of gestational age 24-32 weeks [84].

A strong association between oxidative stress and autoimmunity was shown in a group of 44 Egyptian autistic children, almost $89 \%$ of whom had elevated plasma F2- isoprostane (a marker of lipid peroxidation) and/or reduced glutathione peroxidase (an anti- oxidant enzyme), compared to 44 age-matched controls [85]. Several groups have hypothesized that oxidative stress is the mechanism by which perinatal lipopolysaccharide (LPS) affects neurodevelopment in the offspring [86,87].

Brain region-specific increase in the oxidative stress markers, 3-nitrotyrosine (3-NT) and neurotrophin-3 (NT-3), especially in the cerebellum, were reported in ASD $[88,89]$. Another study evaluating the metabolic status of 55 children with ASD compared to 44 typicallydeveloping children matched for age and sex reported decreased plasma levels of reduced glutathione and increased levels of oxidized glutathione, as well as low levels of S-adenosyl methionine, both major innate antioxidants [90]. Deficiencies in anti-oxidant enzymes might, in certain cases, be associated with mercury toxicity, which was shown to be tightly bound to and inactivate human thioredoxin [91]. In fact, cytosolic and mitochondrial redox imbalance was found in lymphoblastoid cells of ASD children compared to controls, an event exaggerated by exposure to thimerosal [92].

\section{Psychological stress}

A higher incidence of stressors at 21-32 weeks gestation, the embryological age at which pathological cerebellar changes are also seen in autism, was associated with offspring developing autism [93]. Postnatal stressors in the first 6 months of life, such as death of relatives, were associated with increased risk of ASD [94]. Variations in early maternal care could affect behavioral responses in the offspring by altering at least the methylation status of the glucocorticoid receptor gene promoter [95]. Maternal stress due to the first child developing autism may also contribute to children born within a year from this first child having a much higher ASD risk [96]. ASD patients have high anxiety levels and are unable to handle stress appropriately [97]. High evening cortisol levels positively correlated to daily stressors in children with autism [98]. Moreover, increase in age of autistic children correlated with increased cortisol levels during social interaction stress [99].

Stress typically results in secretion of corticotropinreleasing hormone $(\mathrm{CRH})$ from the hypothalamus and regulates the hypothalamic-pituitary-adrenal (HPA) axis [100]. Increased plasma levels of $\mathrm{CRH}$ have been linked to preterm labor [102-103]. CRH not only was increased 
in the serum of mothers who delivered preterm babies $[101,103]$, but also correlated with the mother's level of anxiety during that period of pregnancy [104]. Maternal serum $\mathrm{CRH}$ can cross the placenta, and potentially high amounts of CRH could be produced by the placenta itself, in response to external or intrauterine stress $[105,106]$. CRH may have an immunomodulatory role as an autocrine/paracrine mediator of inflammation during reproduction [107]. A number of cytokines, including IL-1 and IL-6, can trigger secretion of CRH from human cultured placental trophoblasts [108]. In turn, CRH stimulates IL-6 release from human peripheral blood mononuclear cells that infiltrate the fetal membranes and the placenta during intrauterine infection [109].

Acute stress also leads to high serum IL-6 that is mast cell-dependent [110]. Mast cell-derived cytokines, such as IL-6, can increase BBB permeability [110,111]. These effects may be related to the apparent compromise of the BBB in ASD patients, as indicated by the presence of circulating auto-antibodies against brain peptides [112-116]. Even though no studies have so far investigated the integrity of $\mathrm{BBB}$ in ASD, BBB disruption appears to precede any pathological or clinical symptoms associated with other brain inflammatory diseases, such as multiple sclerosis [117-119].

Mast cells have been implicated in inflammatory conditions that worsen by stress [120] and in regulating BBB permeability [110]. BBB disruption due to stress is dependent on both CRH [121] and mast cells [122]. $\mathrm{CRH}$ also increases intestinal permeability of human colonic biopsies [123], and has been associated with intestinal inflammation [124]. One of the early effects of immune $\mathrm{CRH}$ is the activation of mast cells and the release of several pro-inflammatory cytokines [125]. Increased circulating $\mathrm{CRH}$, alone or with other molecules, could disrupt the gut-blood-brain barriers directly or through immune cell activation [126] and permit neurotoxic molecules to enter the brain and result in brain inflammation [127], thus contributing to ASD pathogenesis (Figure 1).

CRH can also be secreted from immune cells [128], mast cells [129], skin [130,131] and post-ganglionic nerve endings [132], leading to pro-inflammatory effects [133,134]. Moreover, CRH released from hair follicles can trigger proliferation and maturation of mast cell progenitors [135]. These findings may help explain why many children with ASD report "allergic-like" symptoms often in the absence of sensitivity to typical allergens [136] that implies mast cell activation [137].

\section{Maternal autoimmune diseases}

The relationship between ASD and familial autoimmunity has long been recognized [138] and has been supported by at least three large population-based studies that utilized medical records and physician data. One case-control study, nested within a cohort of infants born in California (between 1995-1999), examined the association of "immune-related conditions" and reported that maternal psoriasis, asthma, hay fever and atopic dermatitis during the second trimester of pregnancy correlated with over two-fold increased risk of ASD in their children [139]. A study of a large pediatric population $(n=689,196$, born in Denmark between 1993-2004), in which 3,325 children were diagnosed with ASD including 1,089 cases of infantile autism, confirmed an association between family history of type 1 diabetes, rheumatoid arthritis, as well as maternal celiac disease and ASD [140]. A significant association between parental rheumatic fever and ASD, as well as several significant correlations between maternal auto-immune diseases and ASD, were also reported in case-control studies $(n=1,227$ ASD cases) based on 3 Swedish registries [141]. A preliminary report also indicated that mothers with mastocytosis, characterized by an increased number of activated mast cells in many organs $[142,143]$, during pregnancy had a higher risk of delivering one or more children with ASD [144].

Auto-antibodies against brain proteins have also been reported in a number of mothers with children who developed ASD [145]. The transfer of such maternal auto-antibodies to the developing fetus during pregnancy could contribute to immune dysregulation and abnormal neurodevelopment in the offspring, possibly contributing to ASD [145-148]. One recent paper provided a different perspective. In this paper, maternal IgG reactivity to certain fetal brain proteins correlated strongly with diagnosis of autism $(\mathrm{p}=0.0005)$, while reactivity to at least one or more proteins correlated strongly with a "broader" diagnosis of ASD [149].

Human studies investigating the role of perinatal infection in the pathogenesis of autism are limited, and have mostly addressed viral infections [150-152] especially rubella $[151,153,154]$. A nationwide study of children in Denmark ( $\mathrm{n}>20,000$, born 1980-2005) reported an increased risk for ASD after maternal viral infection in the first trimester of pregnancy (adjusted hazard ratio $=2.98$; CI: $1.29-7.15)$ or maternal bacterial infection in the second trimester of pregnancy (adjusted hazard ratio $=1.42$; CI: 1.08-1.87) [155]. In spite of some anecdotal reports of the presence of xenotropic murine leukemia virus-related virus (XMRV) antibodies in autistic children, a recent publication detected no such virus in blood, brain or semen samples of ASD patients or their fathers [156]. Moreover, even though XMRV was reported to be present in as many as $60 \%$ of patients with chronic fatigue syndrome [157], recent reports have suggested that these findings may be due to contamination of laboratory reagents [158]. A number of rotaviruses have been isolated from many asymptomatic neonates [159] and could contribute to ASD. 


\section{Auto-inflammation in ASD children}

Some form of autoimmunity has been suspected in ASD [85,160-162]. An endophenotype with complex immune dysfunction appears to be present both in autistic children and their non-autistic siblings [163]. As mentioned earlier, brain specific auto-antibodies are present in the plasma of many ASD individuals $[112,164,165]$. In a cohort of Egyptian autistic children, 54.5\% had antineuronal antibodies [166]. The presence of such auto-antibodies suggests a loss of self-tolerance to neural antigens during early neurodevelopment, but their precise role in autism remains unknown [85,160-162]. In particular, a recent paper reported that about $40 \%$ of children (3.2 years old) from both the Autism Phenome Project and normotypic controls contained auto-antibodies against Macaque cerebellum Golgi neurons; there was no difference except that the children with auto-antibodies had higher scores for behavioral and emotional problems [167].

An inflammatory response in ASD is supported by a number of facts. TNF was increased almost 50 times in the cerebrospinal fluid (CSF) [168], and IL-6 gene expression was increased in the brain [169] of ASD children. CSF and microglia of ASD patients also had high levels of macrophage chemoattractant-protein-1 (MCP-1) [170], which is a potent chemo-attractant for mast cells [171]. In contrast, ASD plasma contained low levels of transforming growth factor-beta1 (TGF$\beta 1)$ [172]. The clinical significance of such results is not clear given some findings from animal experiments. However, brain over-expression of TGF- $\beta 1$ postnatally decreased social interaction in mice [173] but chronic brain TGF- $\beta 1$ over-expression during adulthood led to opposite behavior in adult mice, a finding in agreement with reduced plasma TGF- $\beta 1$ found in ASD patients. In line with the postnatal TGF- $\beta 1$ expression worsening ASD-like symptoms in mice, TGF- $\beta 1$ and IL-9 exacerbated excitotoxic brain lesions through mast cells in mice [174]. It is intriguing that mast cell-derived IL-9 exacerbates newborn brain toxic lesions [175], induces intestinal permeability and predisposes to oral antigen hypersensitivity in children [176]. One recent paper reported that IL-9 induces mast cell release of vascular endothelial growth factor (VEGF) [177] which also inhibits gut mast cell function [178].

Other studies have reported elevations of plasma cytokines $[179,180]$. However, these results have been variable and do not reflect similar changes in animal models of autism. We recently reported that neurotensin (NT) is increased in serum of young children with autism [181] and can stimulate mast cell secretion [182]. We also reported that NT can stimulate secretion of extracellular mitochondrial DNA, which was also increased in the serum of these ASD patients [183]. NT is a brain and gut peptide that contributes to gut inflammation due to acute stress [123] and also acts synergistically with CRH to increase vascular permeability [184], mostly due to the action of $\mathrm{CRH}$ to stimulate selective release of VEGF from mast cells [185].

This finding may add to the mitochondrial dysfunction reported in many patients with ASD [186,187]. This could relate to reduced energy production [188], decreased ability to buffer ROS [189], susceptibility to mercury neurotoxicity, and to increased TNF release $[190,191]$ that may also be associated with extracellular mitochondrial DNA that was found to be increased in serum of young children with autism [183] and act as "autopathogen".

Mast cells are well-known for their leading role in allergic reactions, during which they are stimulated by $\operatorname{IgE}$ binding to high-affinity receptors (FceRI), aggregation of which leads to degranulation and secretion of numerous pre-stored and newly-synthesized mediators, including IL-6 and TNF [192-197]. In addition to IgE, many substances originating in the environment, the intestine or the brain can trigger mast cell activation [137]. These include non-allergic environmental, infectious, neurohormonal and oxidative stress-related triggers, often involving release of mediators selectively, without degranulation $[137,198]$.

\section{Laboratory studies}

Introduction of human systemic lupus erythematosus auto-antibodies to pregnant mice led to cortical impairment in their offspring [199]. Animal studies have shown that maternal immune activation (MIA) can cause both acute and lasting changes in behavior, CNS structure and function in the offspring [200]. Early life stress due to maternal separation in rats resulted in an altered brain-gut axis and was sufficient to increase blood concentrations of pro-inflammatory cytokines after a challenge with LPS [201]. A short period of restraint [202] or maternal deprivation stress [203] also increased the severity of experimental autoimmune encephalomyelitis in rodents. Maternal separation stress and CRH contributed to a dysfunctional mucosal barrier in rodents [204].

In a poly(I:C) mouse model for MIA, co-administration of anti-IL-6 antibody or use of IL-6-/- mice prevented the social deficits and associated gene expression changes in the brain of the offspring [205]. In addition to its direct detrimental effect on the placenta and fetal brain tissue, IL-1 also induces selective release of IL-6 from mast cells [206]. IL-1 receptor antagonism after systemic end-ofgestation exposure to LPS prevented neurodevelopmental anomalies in pregnant rats [207]. Bacterial LPS activates Toll-like receptor-4 (TLR-4) on immune cells leading to synthesis and release of TNF [197], IL-1 and IL-6 [18]. Moreover, viral double-stranded RNA like poly(I:C) 
induces release of TNF and IL-6 without degranulation from mast cells through viral TLR-3 [208].

\section{Conclusions}

Prematurity, low birth weight and perinatal problems may contribute to increase risk of ASD. This status and susceptible genes, especially of the mTOR and Pten pathways, may make the infant more vulnerable to mast cell activation. Mast cells are now considered important in both innate and acquired immunity [209,210], as well as in inflammation [211,212], and obesity [213]. Such processes may define at least one ASD endophenotype that may be more amenable to therapy.

We propose that perinatal mast cell activation by environmental, infectious, neurohormonal and immune triggers could adversely affect neurodevelopment, disrupt the gut-blood-brain barriers, and contribute to focal brain inflammation and ASD (Figure 1). This premise could be further tested by investigating levels of $\mathrm{CRH}, \mathrm{NT}$ and mtDNA in archived mother and infant blood and comparing the levels between those cases that eventually have children that develop ASD and neurotypic children. Moreover, well-designed studies could be conducted measuring potential biomarkers and providing evidence of allergic and non-allergic mast cell activation postnatally, and particularly at times of developmental regression. Reduction of stress during gestation and infancy, decrease in brain inflammation and/or mast cell activation (especially with some natural flavonoids $[214,215]$ such as luteolin $[216,217]$, which was recently shown to have some benefit in ASD [218]) may prove useful in at least a subgroup of infants at high risk for developing autism.

\footnotetext{
Abbreviations

ASD: Autism Spectrum Disorders; PDD-NOS: Disorder-Not Otherwise Specified; CRH: Corticotropin-releasing hormone; MCHAT: Modified Checklist for Autism in Toddlers; LPS: Lipopolysaccharide; BBB: Blood-brain-barrier; ROS: Reactive oxygen species; NPBI: Non-protein bound iron; 3-NT: 3nitrotyrosine; 3NT-3: Neurotrophin; DSM IV: Diagnostic and Statistical Manual of Mental Disorders; MIA: Maternal immune activation; TLR: Toll-like receptor; TNF: Tumor necrosis factor; poly(l:C): Polyinosinic:polycytidylic acid; XMRV: Xenotropic murine leukemia virus-related virus; CSF: Cerebrospinal fluid; MCP-1: Macrophage chemo-attractant protein-1; TGF- $\beta 1$ : Transforming growth factor-beta1; NT: Neurotensin; VEGF: Vascular endothelial growth factor; JAK2/STAT3: Janus tyrosine kinase-2/signal transducer and activator of transcription-3.
}

\section{Competing interests}

The authors declare that there is no competing interest that could be perceived as prejudicing the impartiality of the research reported.

\section{Authors' contributions}

All authors have read and approved the final manuscript. TCT designed and wrote most of the paper. AA, SA, and K-DA, SK researched the literature and prepared the manuscript, while S.K. reviewed it and offered comments and suggestions.

\section{Financial support}

Aspects of the research mentioned here were funded in part by grants awarded to TCT from Safe Minds, the National Autism Association, the
Autism Research Collaborative, the Autism Research Institute, as well as Theta Biomedical Consulting and Development Co., Inc. (Brookline, MA).

\section{Acknowledgements}

A.A. and K-D.A. were recipients of scholarships for postgraduate studies from the Hellenic State Scholarships Foundation (Athens, Greece).

\section{Author details}

'Molecular Immunopharmacology and Drug Discovery Laboratory, Department of Molecular Physiology and Pharmacology, Tufts University School of Medicine and Tufts Medical Center, Boston, MA 02111, USA. ${ }^{2}$ Department of Biochemistry, Tufts University School of Medicine and Tufts Medical Center, Boston, MA 02111, USA. ${ }^{3}$ Department of Internal Medicine, Tufts University School of Medicine and Tufts Medical Center, Boston, MA 02111, USA. ${ }^{4}$ Department of Psychiatry, Tufts University School of Medicine and Tufts Medical Center, Boston, MA 02111, USA. ${ }^{5}$ Department of Pharmacy, Tufts Medical Center, Boston, MA 02111, USA. ${ }^{6}$ Allergy Clinical Research Center, Allergy Section, Attikon General Hospital, Medical School, Athens 12462, Greece. ${ }^{7}$ Division of Newborn Medicine, Children's Hospital Boston, Harvard Medical School, Boston, MA 02115, USA. ${ }^{8}$ Department of Pediatrics, University of Texas Southwestern, Childrens Medical Center, Dallas, TX 75235, USA. ${ }^{9}$ Department of Internal Medicine, University of Texas Southwestern Medical Center, Dallas, TX 75390, USA.

Received: 13 July 2011 Accepted: 28 May 2012

Published: 2 July 2012

\section{References}

1. Johnson $C P$, Myers SM: Identification and evaluation of children with autism spectrum disorders. Pediatrics 2007, 120:1183-1215.

2. Volkmar FR, State M, Klin A: Autism and autism spectrum disorders: diagnostic issues for the coming decade. J Child Psychol Psychiatry 2009, 50:108-115.

3. Matson JL, Kozlowski AM: Autistic regression. Res Autism Spectr Disord 2010, 4:340-345.

4. Zappella M: Autistic regression with and without EEG abnormalities followed by favourable outcome. Brain Dev 2010, 32:739-745.

5. Fombonne E: Epidemiology of pervasive developmental disorders. Pediatr Res 2009, 65:591-598.

6. Kogan MD, Blumberg SJ, Schieve LA, Boyle CA, Perrin JM, Ghandour RM, Singh GK, Strickland BB, Trevathan E, van Dyck PC: Prevalence of parentreported diagnosis of autism spectrum disorder among children in the US, 2007. Pediatrics 2009, 5:1395-1403.

7. Luft R, Efendic S, Hokfelt T: Somatostatin: both hormone and neurotransmitter? Diabetologia 1978, 14:1-13.

8. Levy SE, Mandell DS, Schultz RT: Autism. Lancet 2009, 374:1627-1638.

9. Durkin MS, Maenner MJ, Meaney FJ, Levy S, DiGuiseppi C, Nicholas JS, Kirby RS, Pinto-Martin JA, Schieve LA: Socioeconomic inequality in the prevalence of autism spectrum disorder: evidence from a U.S. cross-sectional study. PLOS One 2010, 5:11551. e.

10. Herbert MR: Contributions of the environment and environmentally vulnerable physiology to autism spectrum disorders. Curr Opin Neurol 2010, 23:103-110.

11. Miles JH: Autism spectrum disorders-A genetics review. Genet Med 2011, 13:278-294.

12. Careaga M, Van de WJ, Ashwood P: Immune dysfunction in autism: a pathway to treatment. Neurotherapeutics 2010, 7:283-292.

13. Chez MG, Guido-Estrada N: Immune therapy in autism: historical experience and future directions with immunomodulatory therapy. Neurotherapeutics 2010, 7:293-301.

14. MacDorman MF, Declercq E, Zhang J: Obstetrical intervention and the singleton preterm birth rate in the United States from 1991-2006. Am J Public Health 2010, 100:2241-2247.

15. Vojdani A: Antibodies as predictors of complex autoimmune diseases and cancer. Int J Immunopathol Pharmacol 2008, 21(3):553-566. Erratum in: Int J Immunopathol Pharmacol. 2008 Oct-Dec;21(4):following 1051. PMID:18831922.

16. Jauniaux E, Van Oppenraaij RH, Burton GJ: Obstetric outcome after early placental complications. Curr Opin Obstet Gynecol 2010, 22:452-457.

17. Dubicke A, Fransson E, Centini G, Andersson E, Bystrom B, Malmstrom A, Petraglia F, Sverremark-Ekstrom E, Ekman-Ordeberg G: Pro-inflammatory 
and anti-inflammatory cytokines in human preterm and term cervical ripening. J Reprod Immunol 2010, 84:176-185.

18. Snegovskikh W, Schatz F, Arcuri F, Toti P, Kayisli UA, Murk W, Guoyang L, Lockwood CJ, Norwitz ER: Intra-amniotic infection upregulates decidual cell vascular endothelial growth factor (VEGF) and neuropilin-1 and -2 expression: implications for infection-related preterm birth. Reprod Sci 2009, 16:767-780.

19. Thaxton JE, Nevers TA, Sharma S: TLR-mediated preterm birth in response to pathogenic agents. Infect Dis Obstet Gynecol 2010, 2010:-. 378472. Epub 2010 Aug 23.

20. Limperopoulos C, Bassan H, Sullivan NR, Soul JS, Robertson RL Jr, Moore M, Ringer SA, Volpe JJ, du Plessis AJ: Positive screening for autism in ex-preterm infants: prevalence and risk factors. Pediatrics 2008, 121:758-765.

21. Johnson S, Hollis C, Kochhar P, Hennessy E, Wolke D, Marlow N: Autism spectrum disorders in extremely preterm children. J Pediatr 2010, 156:525-531.

22. Martin JA: Preterm Births -- United States, 2007. MMWR Surveill Summ 2011, 60:78-79.

23. Adams-Chapman I: Neurodevelopmental outcome of the late preterm infant. Clin Perinatol 2006, 33:947-964.

24. Argyropoulou Ml: Brain lesions in preterm infants: initial diagnosis and follow-up. Pediatr Radiol 2010, 40:811-818.

25. Valent $P$, Akin C, Arock M, Brockow K, Butterfield JH, Carter MC, Castells $M$ Escribano L, Hartmann K, Lieberman P, Nedoszytko B, Orfao A, Schwartz LB, Sotlar K, Sperr WR, Triggiani M, Valenta R, Horny HP, Metcalfe DD: Definitions, criteria and global classification of mast cell disorders with special reference to mast cell activation syndromes: a consensus proposal. Int Arch Allergy Immunol 2012, 157(3):215-25. Epub 2011 Oct 27.

26. Volpe Jj: The encephalopathy of prematurity-brain injury and impaired brain development inextricably intertwined. Semin Pediatr Neurol 2009, 16:167-178.

27. Johnson S, Marlow N: Preterm birth and childhood psychiatric disorders. Pediatr Res 2011, 69(5 Pt 2):11R-8R.

28. Limperopoulos C: Autism spectrum disorders in survivors of extreme prematurity. Clin Perinatol 2009, 36:791-805. vi.

29. Kaindl AM, Favrais G, Gressens P: Molecular mechanisms involved in injury to the preterm brain. J Child Neurol 2009, 24:1112-1118.

30. Elovitz MA, Brown AG, Breen K, Anton L, Maubert M, Burd I: Intrauterine inflammation, insufficient to induce parturition, still evokes fetal and neonatal brain injury. Int J Dev Neurosci 2011, 29:663-671.

31. Lin CY, Chang YC, Wang ST, Lee TY, Lin CF, Huang CC: Altered inflammatory responses in preterm children with cerebral palsy. Ann Neurol 2010, 68:204-212.

32. Rovira N, Alarcon A, Iriondo M, Ibañez M, Poo P, Cusi V, Agut T, Pertierra A, Krauel X: Impact of histological chorioamnionitis, funisitis and clinical chorioamnionitis on neurodevelopmental outcome of preterm infants. Early Hum Dev 2011, 87(4):253-257. Epub 2011 Feb 26. PMID:21354722.

33. Limperopoulos C, Bassan H, Gauvreau K, Robertson RL Jr, Sullivan NR, Benson CB, Avery L, Stewart J, Soul JS, Ringer SA, Volpe JJ, duPlessis AJ: Does cerebellar injury in premature infants contribute to the high prevalence of long-term cognitive, learning, and behavioral disability in survivors? Pediatrics 2007, 120:584-593.

34. Amin SB, Smith T, Wang H: Is neonatal jaundice associated with Autism Spectrum Disorders: a systematic review. J Autism Dev Disord 2011, 41:1455-1463.

35. Levy S, Zoltak B, Saelens T: A comparison of obstetrical records of autistic and nonautistic referrals for psychoeducational evaluations. J Autism Dev Disord 1988, 18:573-581.

36. Schieve LA, Baio J, Rice CE, Durkin M, Kirby RS, Drews-Botsch C, Miller LA, Nicholas JS, Cunniff CM: Risk for cognitive deficit in a population-based sample of U.S. children with autism spectrum disorders: variation by perinatal health factors. Disabil Health J 2010, 3:202-212.

37. Ehninger D, Sano Y, de Vries PJ, Dies K, Franz D, Geschwind DH, Kaur M, Lee YS, Li W, Lowe JK, Nakagawa JA, Sahin M, Smith K, Whittemore V, Silva AJ: Gestational immune activation and Tsc2 haploinsufficiency cooperate to disrupt fetal survival and may perturb social behavior in adult mice. $\mathrm{Mol}$ Psychiatry 2012, 17(1):62-70. doi:10.1038/mp.2010.115. Epub 2010 Nov 16. Erratum in: Mol Psychiatry. 2012 Apr;17(4):469. PMID:21079609.

38. Kleinman JM, Robins DL, Ventola PE, Pandey J, Boorstein HC, Esser EL, Wilson LB, Rosenthal MA, Sutera S, Verbalis AD, Barton M, Hodgson S, Green J, Dumont-Mathieu T, Volkmar F, Chawarska K, Klin A, Fein D: The modified checklist for autism in toddlers: a follow-up study investigating the early detection of autism spectrum disorders. J Autism Dev Disord 2008, 38:827-839.

39. Pinto-Martin JA, Levy SE, Feldman JF, Lorenz JM, Paneth $N$, Whitaker AH: Prevalence of autism spectrum disorder in adolescents born weighing $<2000$ grams. Pediatrics 2011, 128:883-891.

40. Maimburg RD, Vaeth M: Perinatal risk factors and infantile autism. Acta Psychiatr Scand 2006, 114:257-264.

41. Brimacombe $M$, Ming $X$, Lamendola M: Prenatal and birth complications in autism. Matern Child Health J 2007, 11:73-79.

42. Buchmayer $S$, Johansson S, Johansson A, Hultman CM, Sparen $P$, Cnattingius $\mathrm{S}$ : Can association between preterm birth and autism be explained by maternal or neonatal morbidity? Pediatrics 2009, 124:e817-e825.

43. Hultman CM, Sparen $P$, Cnattingius S: Perinatal risk factors for infantile autism. Epidemiology 2002, 13:417-423.

44. Dodds L, Fell DB, Shea S, Armson BA, Allen AC, Bryson S: The role of prenatal, obstetric and neonatal factors in the development of autism. J Autism Dev Disord 2010.

45. Gardener H, Spiegelman D, Buka SL: Prenatal risk factors for autism: comprehensive meta-analysis. Br J Psychiatry 2009, 195:7-14.

46. Lord C, Mulloy C, Wendelboe M, Schopler E: Pre- and perinatal factors in high-functioning females and males with autism. J Autism Dev Disord 1991, 21:197-209.

47. Gluckman PD, Lillycrop KA, Vickers MH, Pleasants AB, Phillips ES, Beedle AS, Burdge GC, Hanson MA: Metabolic plasticity during mammalian development is directionally dependent on early nutritional status. Proc Natl Acad Sci U S A 2007, 104:12796-12800.

48. Stein D, Weizman A, Ring A, Barak Y: Obstetric complications in individuals diagnosed with autism and in healthy controls. Compr Psychiatry 2006, 47:69-75.

49. Theoharides TC, Makris M, Kalogeromitros D: Allergic inflammation and adipocytokines. Int J Immunopathol Pharmacol 2008, 21:1-4.

50. Tilg H, Moschen AR: Adipocytokines: mediators linking adipose tissue, inflammation and immunity. Nat Rev Immunol 2006, 6:772-783.

51. Considine RV, Sinha MK, Heiman ML, Kriauciunas A, Stephens TW, Nyce MR, Ohannesian JP, Marco CC, McKee LJ, Bauer TL: Serum immunoreactiveleptin concentrations in normal-weight and obese humans. N Engl J Med 1996, 334:292-295.

52. Dardeno TA, Chou SH, Moon HS, Chamberland JP, Fiorenza CG, Mantzoros CS: Leptin in human physiology and therapeutics. Front Neuroendocrinol 2010, 31:377-393.

53. Hauguel-de MS, Lepercq J, Catalano P: The known and unknown of leptin in pregnancy. Am J Obstet Gynecol 2006, 194:1537-1545.

54. Ashwood P, Kwong C, Hansen R, Hertz-Picciotto I, Croen L, Krakowiak P, Walker W, Pessah IN, Van de Water JV: Brief Report: Plasma leptin levels are elevated in autism: Association with early onset phenotype? J Autism Dev Disord 2007, 38:169-175.

55. Blardi P, De LA, D'Ambrogio T, GV, LC, AA, JH: Long-term plasma levels of leptin and adiponectin in Rett Syndrome. Clin Endocrinol (Oxf) 2008, 70:706-709.

56. Vickers MH, Gluckman PD, Coveny AH, Hofman PL, Cutfield WS, Gertler A Breier BH, Harris M: Neonatal leptin treatment reverses developmental programming. Endocrinology 2005, 146:4211-4216.

57. Taildeman J, Perez-Novo CA, Rottiers I, Ferdinande L, Waeytens A, De C, V, C Bachert, Demetter P, Waelput W, Braet K, Cuvelier CA: Human mast cells express leptin and leptin receptors. Histochem Cell Biol 2009, 131:703-711.

58. Sacco R, Curatolo P, Manzi B, Militerni R, Bravaccio C, Frolli A, Lenti C, Saccani M, Elia M, Reichelt KL, Pascucci T, Puglisi-Allegra S, Persico AM: Principal pathogenetic components and biological endophenotypes in autism spectrum disorders. Autism Res 2010, 3:237-252.

59. Weiss LA, Arking DE, Daly MJ, Chakravarti A: A genome-wide linkage and association scan reveals novel loci for autism. Nature 2009, 461:802-808.

60. Smalley SL: Autism and tuberous sclerosis. J Autism Dev Disord 1998, 28:407-414

61. Wulffaert J, Van Berckelaer-Onnes IA, Scholte EM: Autistic disorder symptoms in Rett syndrome. Autism 2009, 13:567-581.

62. Ronald A, Hoekstra RA: Autism spectrum disorders and autistic traits: a decade of new twin studies. Am J Med Genet B Neuropsychiatr Genet 2011, 156B:255-274.

63. Hallmayer J, Cleveland S, Torres A, Phillips J, Cohen B, Torigoe T, Miller J, Fedele A, Collins J, Smith K, Lotspeich L, Croen LA, Ozonoff S, Lajonchere C, Grether JK, Risch N: Genetic heritability and shared environmental factors 
among twin pairs with autism. Arch Gen Psychiatry 2011, 68(11):1095-1102. doi:10.1001/archgenpsychiatry.2011.76. Epub 2011 Jul 4. PMID:21727249.

64. Deth R, Muratore C, Benzecry J, Power-Charnitsky VA, Waly M: How environmental and genetic factors combine to cause autism: A redox/ methylation hypothesis. NeuroToxicol 2008, 29:190-201.

65. Zhang TY, Meaney MJ: Epigenetics and the environmental regulation of the genome and its function. Annu Rev Psychol 2010, 61:439-449.

66. Hoeffer CA, Klann E: mTOR signaling: at the crossroads of plasticity, memory and disease. Trends Neurosci 2010, 33:67-75.

67. Redfern RE, Daou MC, Li L, Munson M, Gericke A, Ross AH: A mutant form of PTEN linked to autism. Protein Sci 2010, 19:1948-1956.

68. Kim MS, Kuehn HS, Metcalfe DD, Gilfillan AM: Activation and function of the mTORC1 pathway in mast cells. J Immunol 2008, 180:4586-4595.

69. Furumoto Y, Charles N, Olivera A, Leung WH, Dillahunt S, Sargent JL, Tinsley K, Odom S, Scott E, Wilson TM, Ghoreschi K, Kneilling M, Chen M, Lee DM, Bolland S, Rivera J: PTEN deficiency in mast cells causes a mastocytosislike proliferative disease that heightens allergic responses and vascular permeability. Blood 2011, 118:5466-5475.

70. Larsson HJ, Eaton WW, Madsen KM, Vestergaard M, Olesen AV, Agerbo E, Schendel D, Thorsen P, Mortensen PB: Risk factors for autism: perinatal factors, parental psychiatric history, and socioeconomic status. Am J Epidemiol 2005, 161:916-925.

71. Gentile S: Drug treatment for mood disorders in pregnancy. Curr Opin Psychiatry 2011, 24:34-40.

72. DiMaggio C, Sun LS, Li G: Early childhood exposure to anesthesia and risk of developmental and behavioral disorders in a sibling birth cohort. Anesth Analg 2011, 113:1143-1151.

73. Sprung J, Flick RP, Katusic SK, Colligan RC, Barbaresi WJ, Bojanic K, Welch TL, Olson MD, Hanson AC, Schroeder DR, Wilder RT, Warner DO: Attentiondeficit/hyperactivity disorder after early exposure to procedures requiring general anesthesia. Mayo Clin Proc 2012, 87:120-129.

74. Young HA, Geier DA, Geier MR: Thimerosal exposure in infants and neurodevelopmental disorders: an assessment of computerized medical records in the Vaccine Safety Datalink. J Neurol Sci 2008, 271:110-118.

75. Hertz-Picciotto I, Park HY, Dostal M, Kocan A, Trnovec T, Sram R: Prenatal exposures to persistent and non-persistent organic compounds and effects on immune system development. Basic Clin Pharmacol Toxicol 2008, 102:146-154.

76. Grandjean P, Landrigan PJ: Developmental neurotoxicity of industrial chemicals. Lancet 2006, 368:2167-2178.

77. Asadi S, Zhang B, Weng Z, Angelidou A, Kempuraj D, Alysandratos KD, Theoharides TC: Luteolin and thiosalicylate inhibit $\mathrm{HgCl}(2)$ and thimerosal-induced VEGF release from human mast cells. Int J Immunopathol Pharmacol 2010, 23:1015-1020.

78. Kempuraj D, Asadi S, Zhang B, Manola A, Hogan J, Peterson E, Theoharides TC: Mercury induces inflammatory mediator release from human mast cells. J Neuroinflammation 2010, 7:20. PMID:20222982.

79. Kwon O, Lee E, Moon TC, Jung H, Lin CX, Nam KS, Baek SH, Min HK, Chang $\mathrm{HW}$ : Expression of cyclooxygenase-2 and pro-inflammatory cytokines induced by $2,2^{\prime}, 4,4^{\prime}, 5,5^{\prime}$-hexachlorobiphenyl (PCB 153) in human mast cells requires NF-kappa B activation. Biol Pharm Bull 2002, 25:1165-1168.

80. Viora M, Quaranta MG, Straface E, Vari R, Masella R, Malorni W: Redox imbalance and immune functions: opposite effects of oxidized lowdensity lipoproteins and N-acetylcysteine. Immunology 2001, 104:431-438.

81. Ingelfinger JR: Prematurity and the legacy of intrauterine stress. N Engl J Med 2007, 356:2093-2095.

82. Joshi SR, Mehendale SS, Dangat KD, Kilari AS, Yadav HR, Taralekar VS: High maternal plasma antioxidant concentrations associated with preterm delivery. Ann Nutr Metab 2008, 53:276-282.

83. Davis JM, Auten RL: Maturation of the antioxidant system and the effects on preterm birth. Semin Fetal Neonatal Med 2010, 15:191-195.

84. Perrone S, Tataranno ML, Negro S, Longini M, Marzocchi B, Proietti F, lacoponi F, Capitani S, Buonocore G: Early identification of the risk for free radical-related diseases in preterm newborns. Early Hum Dev 2010, 86:241-244.

85. Mostafa GA, Kitchener N: Serum anti-nuclear antibodies as a marker of autoimmunity in Egyptian autistic children. Pediatr Neurol 2009, 40:107-112.

86. Lante F, Meunier J, Guiramand J, De Jesus Ferreira MC, Cambonie G, Aimar R, Cohen-Solal C, Maurice T, Vignes M, Barbanel G: Late N-acetylcysteine treatment prevents the deficits induced in the offspring of dams exposed to an immune stress during gestation. Hippocampus 2008, 18:602-609.

87. Paintlia MK, Paintlia AS, Contreras MA, Singh I, Singh AK: Lipopolysaccharide-induced peroxisomal dysfunction exacerbates cerebral white matter injury: attenuation by $\mathrm{N}$-acetyl cysteine. Exp Neurol 2008, 210:560-576.

88. Sajdel-Sulkowska EM, Lipinski B, Windom H, Audhya T, McGinnis W: Oxidative stress in autism: elevated cerebellar 3-nitrotyrosine levels. Am J Biochem Biotechnol 2008, 4:73-84.

89. Sajdel-Sulkowska EM, Xu M, McGinnis W, Koibuchi N: Brain region-specific changes in oxidative stress and neurotrophin levels in autism spectrum disorders (ASD). Cerebellum 2011, 10:43-48.

90. Adams JB, Audhya T, Donough-Means S, Rubin RA, Quig D, Geis E, Gehn E, Loresto M, Mitchell J, Atwood S, Barnhouse S, Lee W: Nutritional and Metabolic Status of Children with Autism vs. Neurotypical Children, and the Association with Autism Severity. Nutr Metab 2011, 8:34. Lond.

91. Carvalho CM, Chew EH, Hashemy SI, Lu J, Holmgren A: Inhibition of the human thioredoxin system. A molecular mechanism of mercury toxicity. J Biol Chem 2008, 283:11913-11923.

92. James SJ, Rose S, Melnyk S, Jernigan S, Blossom S, Pavliv O, Gaylor DW: Cellular and mitochondrial glutathione redox imbalance in lymphoblastoid cells derived from children with autism. FASEB J 2009, 23(8):2374-83. Epub 2009 Mar 23. PMID:19307255.

93. Beversdorf DQ, Manning SE, Hillier A, Anderson SL, Nordgren RE, Walters SE, Nagaraja HN, Cooley WC, Gaelic SE, Bauman ML: Timing of prenatal stressors and autism. J Autism Dev Disord 2005, 35:471-478.

94. Kinney DK, Munir KM, Crowley DJ, Miller AM: Prenatal stress and risk for autism. Neurosci Biobehav Rev 2008, 32:1519-1532.

95. Weaver IC, Cervoni N, Champagne FA, D'Alessio AC, Sharma S, Seckl JR, Dymov S, Szyf M, Meaney MJ: Epigenetic programming by maternal behavior. Nat Neurosci 2004, 7:847-854.

96. Cheslack-Postava K, Liu K, Bearman PS: Closely spaced pregnancies are associated with increased odds of autism in California sibling births. Pediatrics 2011, 127(2):246-253. Epub 2011 Jan 10. PMID:21220394.

97. Gillott A, Standen PJ: Levels of anxiety and sources of stress in adults with autism. J Intellect Disabil 2007, 11:359-370.

98. Corbett BA, Schupp CW, Levine S, Mendoza S: Comparing cortisol, stress, and sensory sensitivity in children with autism. Autism Res 2009, 2:39-49.

99. Corbett BA, Schupp CW, Simon D, Ryan N, Mendoza S: Elevated cortisol during play is associated with age and social engagement in children with autism. Mol Autism 2010, 1:13.

100. Chrousos GP: The hypothalamic-pituitary-adrenal axis and immunemediated inflammation. N Engl J Med 1995, 332:1351-1362.

101. Campbell EA, Linton EA, Wolfe CD, Scraggs PR, Jones MT, Lowry PJ: Plasma corticotropin-releasing hormone concentrations during pregnancy and parturition. J Clin Endocrinol Metab 1987, 64:1054-1059.

102. Mancuso RA, Schetter CD, Rini CM, Roesch SC, Hobel CJ: Maternal prenatal anxiety and corticotropin-releasing hormone associated with timing of delivery. Psychosom Med 2004, 66:762-769.

103. Warren WB, Patrick SL, Goland RS: Elevated maternal plasma corticotropinreleasing hormone levels in pregnancies complicated by preterm labor. Am J Obstet Gynecol 1992, 166:1198-1204.

104. Makrigiannakis A, Semmler M, Briese V, Eckerle H, Minas V, Mylonas I, Friese $\mathrm{K}$, Jeschke U: Maternal serum corticotropin-releasing hormone and ACTH levels as predictive markers of premature labor. Int J Gynaecol Obstet 2007, 97:115-119.

105. Grammatopoulos DK: Placental corticotrophin-releasing hormone and its receptors in human pregnancy and labour: still a scientific enigma. J Neuroendocrinol 2008, 20:432-438.

106. Torricelli M, Novembri R, Bloise E, De BM, Challis JR, Petraglia F: Changes in placental $\mathrm{CRH}$, urocortins, and $\mathrm{CRH}$-receptor mRNA expression associated with preterm delivery and chorioamnionitis. J Clin Endocrinol Metab 2011, 96:534-540.

107. Kalantaridou S, Makrigiannakis A, Zoumakis E, Chrousos GP: Peripheral corticotropin-releasing hormone is produced in the immune and reproductive systems: actions, potential roles and clinical implications. Front Biosci 2007, 12:572-580.

108. Petraglia F, Garuti GC, De RB, Angioni S, Genazzani AR, Bilezikjian LM: Mechanism of action of interleukin-1 beta in increasing corticotropinreleasing factor and adrenocorticotropin hormone release from cultured human placental cells. Am J Obstet Gynecol 1990, 163:1307-1312. 
109. Angioni S, Petraglia F, Gallinelli A, Cossarizza A, Franceschi C, Muscettola M, Genazzani AD, Surico N, Genazzani AR: Corticotropin-releasing hormone modulates cytokines release in cultured human peripheral blood mononuclear cells. Life Sci 1993, 53:1735-1742.

110. Theoharides TC, Konstantinidou A: Corticotropin-releasing hormone and the blood-brain-barrier. Front Biosci 2007, 12:1615-1628.

111. Abbott NJ: Inflammatory mediators and modulation of blood-brain barrier permeability. Cell Mol Neurobiol 2000, 20:131-147.

112. Cabanlit M, Wills S, Goines P, Ashwood P, Van de Water J: Brain-specific autoantibodies in the plasma of subjects with autistic spectrum disorder. Ann N Y Acad Sci 2007, 1107:92-103.

113. Goines P, Van de Water J: The immune system's role in the biology of autism. Curr Opin Neurol 2010, 23:111-117.

114. Singer HS, Morris CM, Williams PN, Yoon DY, Hong JJ, Zimmerman AW: Antibrain antibodies in children with autism and their unaffected siblings. J Neuroimmunol 2006, 178:149-155

115. Vojdani A: Antibodies as predictors of complex autoimmune diseases. Int $\mathrm{J}$ Immunopath Pharmacol 2008, in press.

116. Wills S, Cabanlit M, Bennett J, Ashwood P, Amaral DG, Van de WJ: Detection of autoantibodies to neural cells of the cerebellum in the plasma of subjects with autism spectrum disorders. Brain Behav Immun 2009, 23:64-74.

117. Minagar A, Alexander JS: Blood-brain barrier disruption in multiple sclerosis. Mult Scler 2003, 9:540-549.

118. Soon D, Altmann DR, Fernando KT, Giovannoni G, Barkhof F, Polman CH, O'Connor P, Gray B, Panzara M, Miller DH: A study of subtle blood brain barrier disruption in a placebo-controlled trial of natalizumab in relapsing remitting multiple sclerosis. J Neurol 2007, 254:306-314.

119. Stone LA, Smith ME, Albert PS, Bash CN, Maloni H, Frank JA, McFarland HF: Blood-brain barrier disruption on contrast-enhanced MRI in patients with mild relapsing-remitting multiple sclerosis: Relationship to course, gender, and age. Neurology 1995, 45:1122-1126.

120. Theoharides TC, Cochrane DE: Critical role of mast cells in inflammatory diseases and the effect of acute stress. J Neuroimmunol 2004, 146:1-12.

121. Esposito P, Chandler N, Kandere-Grzybowska K, Basu S, Jacobson S, Connolly $\mathrm{R}$, Tutor D, Theoharides TC: Corticotropin-releasing hormone (CRH) and brain mast cells regulate blood-brain-barrier permeability induced by acute stress. J Pharmacol Exp Ther 2002, 303:1061-1066.

122. Esposito P, Gheorghe D, Kandere K, Pang X, Conally R, Jacobson S, Theoharides TC: Acute stress increases permeability of the blood-brain-barrier through activation of brain mast cells. Brain Res 2001, 888:117-127.

123. Castagliuolo I, Leeman SE, Bartolac-Suki E, Nikulasson S, Qiu B, Carraway RE, Pothoulakis C: A neurotensin antagonist, SR 48692, inhibits colonic responses to immobilization stress in rats. Proc Natl Acad Sci USA 1996, 93:12611-12615.

124. Pothoulakis C, Castagliuolo I, Leeman SE: Neuroimmune mechanisms of intestinal responses to stress, Role of corticotropin-releasing factor and neurotensin. Ann N Y Acad Sci 1998, 840:635-648.

125. Theoharides TC, Donelan JM, Papadopoulou N, Cao J, Kempuraj D, Conti P: Mast cells as targets of corticotropin-releasing factor and related peptides. Trends Pharmacol Sci 2004, 25:563-568.

126. Theoharides TC, Doyle R: Autism, gut-blood-brain barrier and mast cells. J Clin Psychopharmacol 2008, 28:479-483.

127. Theoharides TC, Doyle R, Francis K, Conti P, Kalogeromitros D: Novel therapeutic targets for autism. Trends Pharmacol Sci 2008, 29:375-382.

128. Karalis K, Louis JM, Bae D, Hilderbrand H, Majzoub JA: CRH and the immune system. J Neuroimmunol 1997, 72:131-136.

129. Kempuraj D, Papadopoulou NG, Lytinas M, Huang M, Kandere-Grzybowska K, Madhappan B, Boucher W, Christodoulou S, Athanassiou A, Theoharides TC: Corticotropin-releasing hormone and its structurally related urocortin are synthesized and secreted by human mast cells. Endocrinology 2004, 145:43-48.

130. Slominski A, Wortsman J, Pisarchik A, Zbytek B, Linton EA, Mazurkiewicz JE, Wei ET: Cutaneous expression of corticotropin-releasing hormone (CRH), urocortin, and CRH receptors. FASEB J 2001, 15:1678-1693.

131. Slominski A, Zbytek B, Zmijewski M, Slominski RM, Kauser S, Wortsman J, Tobin DJ: Corticotropin releasing hormone and the skin. Front Biosci 2006, 11:2230-2248.

132. Skofitsch G, Zamir N, Helke CJ, Savitt JM, Jacobowitz DM: Corticotropinreleasing factor-like immunoreactivity in sensory ganglia and capsaicin sensitive neurons of the rat central nervous system: colocalization with other neuropeptides. Peptides 1985, 6:307-318.

133. Singh LK, Pang X, Alexacos N, Letourneau R, Theoharides TC: Acute immobilization stress triggers skin mast cell degranulation via corticotropin-releasing hormone, neurotensin and substance P: A link to neurogenic skin disorders. Brain Behav Immunity 1999, 13:225-239.

134. Theoharides TC, Singh LK, Boucher W, Pang X, Letourneau R, Webster E, Chrousos G: Corticotropin-releasing hormone induces skin mast cell degranulation and increased vascular permeability, a possible explanation for its pro-inflammatory effects. Endocrinology 1998, 139:403-413.

135. Ito N, Sugawara K, Bodo E, Takigawa M, Van BN, Ito T, Paus R: Corticotropinreleasing hormone stimulates the in situ generation of mast cells from precursors in the human hair follicle mesenchyme. J Invest Dermatol 2010, 130:995-1004.

136. Angelidou A, Alysandratos KD, Asadi S, Zhang B, Francis K, Vasiadi M, Kalogeromitros D, Theoharides TC: Brief Report: "Allergic Symptoms" in children with Autism Spectrum Disorders. In More than meets the eye, J Autism Dev Disord. 41st edition. 2011:1579-1585.

137. Theoharides TC, Angelidou A, Alysandratos KD, Zhang B, Asadi S, Francis K, Toniato E, Kalogeromitros D: Mast cell activation and autism. Biochim Biophys Acta 2012, 1822:34-41.

138. Money J, Bobrow NA, Clarke FC: Autism and autoimmune disease: a family study. J Autism Child Schizophr 1971, 1:146-160.

139. Croen LA, Grether JK, Yoshida CK, Odouli R, Van de WJ: Maternal autoimmune diseases, asthma and allergies, and childhood autism spectrum disorders: a case-control study. Arch Pediatr Adolesc Med 2005, 159:151-157.

140. Atladottir HO, Pedersen MG, Thorsen P, Mortensen PB, Deleuran B, Eaton WW, Parner ET: Association of family history of autoimmune diseases and autism spectrum disorders. Pediatrics 2009, 124:687-694.

141. Keil A, Daniels JL, Forssen U, Hultman C, Cnattingius S, Soderberg KC, Feychting M, Sparen P: Parental autoimmune diseases associated with autism spectrum disorders in offspring. Epidemiology 2010, 21:805-808.

142. Akin C, Valent P, Metcalfe DD: Mast cell activation syndrome: Proposed diagnostic criteria. J Allergy Clin Immunol 2010, 126(6):104.e4-1099.e4. Epub 2010 Oct 28. PMID:21035176.

143. Castells M, Austen KF: Mastocytosis: mediator-related signs and symptoms. Int Arch Allergy Immunol 2002, 127:147-152.

144. Theoharides TC: Autism spectrum disorders and mastocytosis. Int J Immunopathol Pharmacol 2009, 22:859-865

145. Croen LA, Braunschweig D, Haapanen L, Yoshida CK, Fireman B, Grether JK, Kharrazi M, Hansen RL, Ashwood P, Van de WJ: Maternal mid-pregnancy autoantibodies to fetal brain protein: the early markers for autism study. Biol Psychiatry 2008, 64:583-588.

146. Braunschweig D, Ashwood P, Krakowiak P, Hertz-Picciotto I, Hansen R, Croen LA, Pessah IN, Van de Water J: Autism: maternally derived antibodies specific for fetal brain proteins. NeuroToxicol 2008, 29:226-231.

147. Singer HS, Morris CM, Gause CD, Gillin PK, Crawford S, Zimmerman AW: Antibodies against fetal brain in sera of mothers with autistic children. J Neuroimmunol 2008, 194:165-172.

148. Zimmerman AW, Connors SL, Matteson KJ, Lee LC, Singer HS, Castaneda JA, Pearce DA: Maternal antibrain antibodies in autism. Brain Behav Immun 2007, 21:351-357.

149. Braunschweig D, Duncanson P, Boyce R, Hansen R, Ashwood P, Pessah IN, Hertz-Picciotto I, Van de Water J: Behavioral correlates of maternal antibody status among children with autism. J Autism Dev Disord 2012, 42(7):1435-1445. PMID:22012245.

150. Chess S: Follow-up report on autism in congenital rubella. J Autism Child Schizophr 1977, 7:69-81.

151. Libbey JE, Sweeten TL, McMahon WM, Fujinami RS: Autistic disorder and viral infections. J Neurovirol 2005, 11:1-10.

152. Wilkerson DS, Volpe AG, Dean RS, Titus JB: Perinatal complications as predictors of infantile autism. Int J Neurosci 2002, 112:1085-1098.

153. Chess S: Autism in children with congenital rubella. J Autism Child Schizophr 1971, 1:33-47.

154. Richler J, Luyster R, Risi S, Hsu WL, Dawson G, Bernier R, Dunn M, Hepburn S, Hyman SL, McMahon WM, Goudie-Nice J, Minshew N, Rogers S, Sigman M, Spence MA, Goldberg WA, Tager-Flusberg H, Volkmar FR, Lord C: Is there a 'regressive phenotype' of Autism Spectrum Disorder associated with the measles-mumps-rubella vaccine? A CPEA Study. J Autism Dev Disord 2006, 36:299-316. 
155. Atladottir HO, Thorsen $\mathrm{P}$, Ostergaard L, Schendel DE, Lemcke S, Abdallah M, Parner ET: Maternal infection requiring hospitalization during pregnancy and autism spectrum disorders. J Autism Dev Disord 2010, 40:1423-1430.

156. Lintas C, Guidi F, Manzi B, Mancini A, Curatolo P, Persico AM: Lack of infection with XMRV or other MLV-related viruses in blood, post-mortem brains and paternal gametes of autistic individuals. PLoS One 2011, 6:e16609.

157. Lombardi VC, Ruscetti FW, Das Gupta J, Pfost MA, Hagen KS, Peterson DL, Ruscetti SK, Bagni RK, Petrow-Sadowski C, Gold B, Dean M, Silverman RH, Mikovits JA: Detection of an Infectious Retrovirus, XMRV, in Blood Cells of Patients with Chronic Fatigue Syndrome. Science 2009, 326(5952):585-589. Epub 2009 Oct 8 Retraction in: Alberts B. Science. 2011 Dec 23;334(6063):1636. Partial retraction in: Silverman RH, Das Gupta J, Lombardi VC, Ruscetti FW, Pfost MA, Hagen KS, Peterson DL, Ruscetti SK, Bagni RK, Petrow-Sadowski C, Gold B, Dean M, Mikovits JA. Science. 2011 Oct 14;334(6053):176

158. Oakes B, Tai AK, Cingöz O, Henefield MH, Levine S, Coffin JM, Huber BT: Contamination of human DNA samples with mouse DNA can lead to false detection of XMRV-like sequences. Retrovirology 2010, 20(7):109. PMID:21171973.

159. Dunn SJ, Greenberg HB, Ward RL, Nakagomi O, Burns JW, Vo PT, Pax KA, Das M, Gowda K, Rao CD: Serotypic and genotypic characterization of human serotype 10 rotaviruses from asymptomatic neonates. J Clin Microbiol 1993, 31:165-169.

160. Enstrom AM, Van de Water JA, Ashwood P: Autoimmunity in autism. Curr Opin Investig Drugs 2009, 10:463-473.

161. Mostafa GA, El-Sayed ZA, El-Aziz MM, El-Sayed MF: Serum anti-myelinassociated glycoprotein antibodies in Egyptian autistic children. J Child Neurol 2008, 23:1413-1418

162. Wills S, Cabanlit M, Bennett J, Ashwood P, Amaral D, Van de Water J: Autoantibodies in autism spectrum disorders (ASD). Ann N Y Acad Sci 2007, 1107:79-91.

163. Saresella M, Marventano I, Guerini FR, Mancuso R, Ceresa L, Zanzottera M, Rusconi B, Maggioni E, Tinelli C, Clerici M: An autistic endophenotype results in complex immune dysfunction in healthy siblings of autistic children. Biol Psychiatry 2009, 66:978-984.

164. Singh VK, Rivas WH: Prevalence of serum antibodies to caudate nucleus in autistic children. Neurosci Lett 2004, 355:53-56.

165. Singh VK, Warren R, Averett R, Ghaziuddin M: Circulating autoantibodies to neuronal and glial filament proteins in autism. Pediatr Neurol 1997, 17:88-90.

166. Mostafa GA, El-Hadidi ES, Hewedi DH, Abdou MM: Oxidative stress in Egyptian children with autism: relation to autoimmunity. J Neuroimmunol 2010, 219:114-118.

167. Rossi CC, Van de WJ, Rogers SJ, Amaral DG: Detection of plasma autoantibodies to brain tissue in young children with and without autism spectrum disorders. Brain Behav Immun 2011, 25:1123-1135.

168. Chez MG, Dowling T, Patel PB, Khanna P, Kominsky M: Elevation of tumor necrosis factor-alpha in cerebrospinal fluid of autistic children. Pediatr Neurol 2007, 36:361-365.

169. Li X, Chauhan A, Sheikh AM, Patil S, Chauhan V, Li XM, Ji L, Brown T, Malik M: Elevated immune response in the brain of autistic patients. J Neuroimmunol 2009, 207:111-116.

170. Vargas DL, Nascimbene C, Krishnan C, Zimmerman AW, Pardo CA: Neuroglial activation and neuroinflammation in the brain of patients with autism. Ann Neurol 2005, 57:67-81.

171. Conti P, Pang X, Boucher W, Letourneau R, Reale M, Barbacane RC, Thibault J, Theoharides TC: Impact of Rantes and MCP-1 chemokines on in vivo basophilic mast cell recruitment in rat skin injection model and their role in modifying the protein and mRNA levels for histidine decarboxylase. Blood 1997, 89:4120-4127.

172. Ashwood P, Enstrom A, Krakowiak P, Hertz-Picciotto I, Hansen RL, Croen LA Ozonoff S, Pessah IN, Van de Water JV: Decreased transforming growth factor beta1 in autism: A potential link between immune dysregulation and impairment in clinical behavioral outcomes. J Neuroimmunol 2008 , 204:149-153.

173. Depino AM, Lucchina L, Pitossi F: Early and adult hippocampal TGF-beta1 overexpression have opposite effects on behavior. Brain Behav Immun 2011, 25:1582-1591.

174. Jong EC: Travel-related infections: prevention and treatment. Hosp Pract 1989, 24:145-172.
175. Dommergues MA, Patkai J, Renauld JC, Evrard P, Gressens P Proinflammatory cytokines and interleukin- 9 exacerbate excitotoxic lesions of the newborn murine neopallium. Ann Neurol 2000, 47:54-63.

176. Forbes EE, Groschwitz K, Abonia JP, Brandt EB, Cohen E, Blanchard C, Ahrens R, Seidu L, McKenzie A, Strait R, Finkelman FD, Foster PS, Matthaei KI, Rothenberg ME, Hogan SP: IL-9- and mast cell-mediated intestinal permeability predisposes to oral antigen hypersensitivity. J Exp Med 2008, 205:897-913.

177. Sismanopoulos N, Delivanis DA, Alysandratos KD, Angelidou A, Vasiadi M, Therianou A, Theoharides TC: IL-9 induces VEGF secretion from human mast cells and IL-9/IL-9 receptor genes are overexpressed in atopic dermatitis. PLoS One 2012, 7(3):e33271.

178. Gebhardt T, Lorentz A, Detmer F, Trautwein C, Bektas H, Manns MP, Bischoff SC: Growth, phenotype, and function of human intestinal mast cells are tightly regulated by transforming growth factor beta1. Gut 2005, 54:928-934.

179. Ashwood P, Nguyen DV, Hessl D, Hagerman RJ, Tassone F: Plasma cytokine profiles in Fragile $X$ subjects: is there a role for cytokines in the pathogenesis? Brain Behav Immun 2010, 24(6):898-902.

180. Molloy CA, Morrow AL, Meinzen-Derr J, Schleifer K, Dienger K, ManningCourt, Altaye M, Wills-Karp M: Elevated cytokine levels in children with autism spectrum disorder. J Neuroimmunol 2006, 172:198-205.

181. Angelidou A, Francis K, Vasiadi M, Alysandratos K-D, Zhang B Theoharides A, Lykouras L, Kalogeromitros D, Theoharides T: Neurotensin is increased in serum of young children with autistic disorder. J Neuroinflammation 2010, 7:48

182. Carraway R, Cochrane DE, Lansman JB, Leeman SE, Paterson BM, Welch HJ: Neurotensin stimulates exocytotic histamine secretion from rat mast cells and elevates plasma histamine levels. J Physio/ 1982, 323:403-414

183. Zhang B, Angelidou A, Alysandratos KD, Vasiadi M, Francis K, Asadi S, Theoharides A, Theoharides TC, Sideri K, Lykouras L, Kalogeromitros D: Mitochondrial DNA and anti-mitochondrial antibodies in serum of autistic children. J Neuroinflammation 2010, 7:80.

184. Gulubova M, Vlaykova T: Prognostic significance of mast cell number and microvascular density for the survival of patients with primary colorectal cancer. J Gastroenterol Hepatol 2009, 24:1265-1275.

185. Cao J, Papadopoulou N, Kempuraj D, Boucher WS, Sugimoto K, Cetrulo CL, Theoharides TC: Human mast cells express corticotropinreleasing hormone $(\mathrm{CRH})$ receptors and $\mathrm{CRH}$ leads to selective secretion of vascular endothelial growth factor. J Immunol 2005 174:7665-7675.

186. Giulivi C, Zhang YF, Omanska-Klusek A, Ross-Inta C, Wong S, Hertz-Picciotto I, Tassone F, Pessah IN: Mitochondrial dysfunction in autism. JAMA 2010, 304:2389-2396.

187. Palmieri L, Persico AM: Mitochondrial dysfunction in autism spectrum disorders: Cause or effect? Biochim Biophys Acta 2010, 1797:1130-1137.

188. Youle RJ, Karbowski M: Mitochondrial fission in apoptosis. Nat Rev Mol Cell Biol 2005, 6:657-663.

189. Bolanos JP, Almeida A, Stewart V, Peuchen S, Land JM, Clark JB, Heales SJ: Nitric oxide-mediated mitochondrial damage in the brain: mechanisms and implications for neurodegenerative diseases. J Neurochem 1997 68:2227-2240

190. Zhang B, Alysandratos KD, Angelidou A, Asadi S, Sismanopoulos N, Delivanis DA, Weng Z, Miniati A, Vasiadi M, Katsarou-Katsari A, Miao B, Leeman SE, Kalogeromitros D, Theoharides TC: Human mast cell degranulation and preformed TNF secretion require mitochondrial translocation to exocytosis sites: relevance to atopic dermatitis. J Allergy Clin Immunol 2011, 127(6):31.e8-1522.e8. Epub 2011 Mar 31. PMID:21453958

191. Zhang B, Weng Z, Sismanopoulos N, Asadi S, Therianou A, Alysandratos KD, Angelidou A, Shirihai O, Theoharides TC: Mitochondria Distinguish Granule-Stored from de novo Synthesized Tumor Necrosis Factor Secretion in Human Mast Cells. Int Arch Allergy Immunol 2012, 159(1):23-32. [Epub ahead of print] PMID:22555146

192. Blank U, Rivera J: The ins and outs of IgE-dependent mast-cell exocytosis. Trends Immunol 2004, 25:266-273.

193. Kraft S, Kinet JP: New developments in FcepsilonRI regulation, function and inhibition. Nat Rev Immunol 2007, 7:365-378. 
194. Schroeder JT, Kagey-Sobotka A, MacGlashan DW, Lichtenstein LM: The interaction of cytokines with human basophils and mast cells. Int Arch Allergy Immunol 1995, 107:79-81.

195. Schwartz LB: Mediators of human mast cells and human mast cell subsets. Ann Allergy 1987, 58:226-235.

196. Serafin WE, Austen KF: Mediators of immediate hypersensitivity reactions. N Engl J Med 1987, 317:30-34.

197. Torigoe C, Goldstein B, Wofsy C, Metzger H: Shuttling of initiating kinase between discrete aggregates of the high affinity receptor for IgE regulates the cellular response. Proc Natl Acad Sci U S A 1997, 94:1372-1377

198. Theoharides TC, Kempuraj D, Tagen M, Conti P, Kalogeromitros D: Differential release of mast cell mediators and the pathogenesis of inflammation. Immunol Rev 2007, 217:65-78.

199. Lee JY, Huerta PT, Zhang J, Kowal C, Bertini E, Volpe BT, Diamond B: Neurotoxic autoantibodies mediate congenital cortical impairment of offspring in maternal lupus. Nat Med 2009, 15:91-96.

200. Boksa P: Effects of prenatal infection on brain development and behavior: a review of findings from animal models. Brain Behav Immun 2010, 24:881-897.

201. O'Mahony SM, Marchesi JR, Scully P, Codling C, Ceolho AM, Quigley EM, Cryan JF, Dinan TG: Early life stress alters behavior, immunity, and microbiota in rats: implications for irritable bowel syndrome and psychiatric illnesses. Biol Psychiatry 2009, 65:263-267.

202. Chandler N, Jacobson S, Connolly R, Esposito P, Theoharides TC: Acute stress shortens the time of onset of experimental allergic encephalomyelitis (EAE) in SJL/J mice. Brain Behav Immun 2002, 16:757-763.

203. Teunis MA, Heijnen CJ, Sluyter F, Bakker JM, Van Dam AM, Hof M, Cools AR, Kavelaars A: Maternal deprivation of rat pups increases clinical symptoms of experimental autoimmune encephalomyelitis at adult age. J Neuroimmunol 2002, 133:30-38.

204. Soderholm JD, Yates DA, Gareau MG, Yang PC, MacQueen G, Perdue MH: Neonatal maternal separation predisposes adult rats to colonic barrier dysfunction in response to mild stress. Am J Physiol Gastrointest Liver Physiol 2002, 283:G1257-G1263.

205. Smith SE, Li J, Garbett K, Mirnics K, Patterson PH: Maternal immune activation alters fetal brain development through interleukin-6. J Neurosci 2007, 27:10695-10702.

206. Kandere-Grzybowska K, Kempuraj D, Letourneau L, Asare A, Athanasiou A, Theoharides TC: IL-1 induces differential release of IL- 6 form human mast cells. FASEB J 2002, 16(332). A.

207. Girard S, Tremblay L, Lepage M, Sebire G: IL-1 receptor antagonist protects against placental and neurodevelopmental defects induced by maternal inflammation. J Immunol 2010, 184:3997-4005.

208. Kulka M, Alexopoulou L, Flavell RA, Metcalfe DD: Activation of mast cells by double-stranded RNA: evidence for activation through Toll-like receptor 3. J Allergy Clin Immunol 2004, 114:174-182.

209. Galli SJ, Kalesnikoff J, Grimbaldeston MA, Piliponsky AM, Williams CM, Tsai M: Mast cells as "tunable" effector and immunoregulatory cells: recent advances. Annu Rev Immunol 2005, 23:749-786.

210. Galli SJ, Tsai M, Piliponsky AM: The development of allergic inflammation. Nature 2008, 454:445-454.

211. Theoharides TC, Alysandratos KD, Angelidou A, Delivanis DA, Sismanopoulos N, Zhang B, Asadi S, Vasiadi M, Weng Z, Miniati A, Kalogeromitros D: Mast cells and inflammation. Biochim Biophys Acta $2010,1822: 21-33$

212. Theoharides TC, Kalogeromitros D: The critical role of mast cell in allergy and inflammation. Ann NY Acad Sci 2006, 1088:78-99.

213. Liu J, Divoux A, Sun J, Zhang J, Clement K, Glickman JN, Sukhova GK, Wolters PJ, Du J, Gorgun CZ, Doria A, Libby P, Blumberg RS, Kahn BB, Hotamisligil GS, Shi GP: Genetic deficiency and pharmacological stabilization of mast cells reduce diet-induced obesity and diabetes in mice. Nat Med 2009, 15:940-945.

214. Middleton E Jr, Kandaswami C, Theoharides TC: The effects of plant flavonoids on mammalian cells: implications for inflammation, heart disease and cancer. Pharmacol Rev 2000, 52:673-751.

215. Kempuraj D, Madhappan B, Christodoulou S, Boucher W, Cao J, Papadopoulou N, Cetrulo CL, Theoharides TC: Flavonols inhibit proinflammatory mediator release, intracellular calcium ion levels and protein kinase $\mathrm{C}$ theta phosphorylation in human mast cells. $\mathrm{Br} \mathrm{J}$ Pharmacol 2005, 145:934-944.

216. Dirscherl K, Karlstetter M, Ebert S, Kraus D, Hlawatsch J, Walczak Y, Moehle C, Fuchshofer R, Langmann T: Luteolin triggers global changes in the microglial transcriptome leading to a unique anti-inflammatory and neuroprotective phenotype. J Neuroinflammation 2010, 7:3.

217. Jang S, Kelley KW, Johnson RW: Luteolin reduces IL-6 production in microglia by inhibiting JNK phosphorylation and activation of AP-1. ProC Natl Acad Sci U S A 2008, 9(21):7534. Epub 2008 May 19. PMID: 18490655

218. Theoharides TC, Asadi S, Panagiotidou S: A case series of a luteolin formulation (NeuroProtekâ) in children with autism spectrum disorders. Int J Immunopathol Pharmacol 2012, 25(2):317-323. PMID:22697063.

doi:10.1186/1471-2431-12-89

Cite this article as: Angelidou et al.: Perinatal stress, brain inflammation and risk of autism-Review and proposal. BMC Pediatrics 2012 12:89.

\section{Submit your next manuscript to BioMed Central and take full advantage of:}

- Convenient online submission

- Thorough peer review

- No space constraints or color figure charges

- Immediate publication on acceptance

- Inclusion in PubMed, CAS, Scopus and Google Scholar

- Research which is freely available for redistribution 